В. В. Звірич Національний інститут раку, вул. Ломоносова, 33/43, м. Київ, Україна БІЛАТЕРАЛЬНИЙ АВАСКУЛЯРНИЙ НЕКРОЗ ЛАТЕРАЛЬНИХ
МАС КРИЖІВ ПРИ ПОВНОМУ КЛІНІКО-РАДІОЛОГІЧНОМУ
РЕГРЕСІ ПІСЛЯ НЕОАЛ'ЮВАНТНОЇ ХІМІОПРОМЕНЕВОЇ
ТЕРАПІЇ МІСЦЕВО ПОШИРЕНОГО ДИСТАЛЬНОГО РАКУ
ПРЯМОЇ КИШКИ. КЛІНІЧНИЙ ВИПАДОК

Представлено рідкісний клінічний випадок двостороннього аваскулярного некрозу бічних крижових мас у пацієнта з повним клінічним та радіологічним регресом місцево поширеного раку прямої кишки після хіміопроменевої терапії.Показано, що незважаючи на стандартизовану і прецизійну техніку планування, фракціонування і дозиметричного контролю за проведенням неоад'ювантної хіміопроменевої терапії з приводу місцево поширеного раку прямої кишки, біологічні ефекти іонізуючого випромінювання на критичні органи можуть мати різноманітний характер як за часом виникнення, так і за своєю структурою. Оцінюючи ефект неоад'ювантної хіміопроменевої терапії, слід брати до уваги можливість розвитку навіть дуже рідкісних ефектів іонізуючого випромінювання з боку критичних органів і включати їх раннє виявлення в діагностичний алгоритм.

Ключові слова: місцево поширений рак прямої кишки, аваскулярний некроз, неоад'ювантна хіміопроменева терапія.

Проблеми радіаційної медицини та радіобіології. 2019. Вип. 24. C. 537-551. doi: 10.33145/2304-8336-2019-24-537-551

V. V. Zvirych $\varangle$, D. E. Makhmudov, M. I. Paliiy, A. V. Ashykhmin, O. O. Kolesnik

National Cancer Institute, 33/43 Lomonosova St., Kyiv, Ukraine

\title{
BILATERAL AVASCULAR NECROSIS OF SACRAL LATERAL MASSES AFTER A COMPLETE RADIOLOGICAL RESPONSE OF LOCALLY ADVANCED RECTAL CANCER TREATED WITH NEOADJUVANT CHEMORADIATION THERAPY. CASE REPORT
}

We present a rare case report of a bilateral avascular necrosis of lateral sacral masses in a patient who developed a sustainable complete clinical and radiological response after chemoradiotherapy for locally advanced rectal cancer. It is shown that despite the standardized and precise planning and fractioning for neoadjuvant chemoradiation therapy for locally advanced rectal cancer, the biological effects of ionizing radiation on critical organs can be varied both in time of occurrence and in structure. Evaluating the effect of neoadjuvant chemoradiation therapy, one should take into account the possibility of the development of even very rare effects of ionizing radiation on critical organs and include their early detection in the diagnostic algorithm.

Key words: locally advanced rectal cancer, avascular necrosis of lateral sacral masses, neoadjuvant chemoradiation therapy.

Звірич Віталій Васильович, e-mail: zvirvit@ukr.net

Vitalii V. Zvirych, e-mail: zvirvit@ukr.net 


\section{ВСТУП}

Патологічні зміни з боку кісткової системи після променевої терапії злоякісних новоутворень органів малого таза, будучи пізніми проявами постпроменевих реакцій, спостерігаються більш ніж у $30 \%$ пацієнтів. Найчастіше вони відзначаються в тих випадках, коли променева або хіміопроменева терапія $\epsilon$ провідними методами в радикальному лікуванні: 65,6 \% - при раку шийки матки, $18 \%$ - прямої кишки, 10,7 \% - сечового міхура, 5,7 \% - ендометрію [1].

Аваскулярний некроз (АВН), відомий також як інфаркт кісткового мозку, виникає в результаті критичної ішемії останнього на тлі недостатньої мікроциркуляторної перфузії. Цей стан найчастіше виникає в кістках, що кровопостачаються термінальними гілками магістральних артерій із слаборозвиненою сіткою колатералей, таких як голівка стегнової кістки, проксимальний епіметафіз великогомілкової, плечової кістки, таранна, човноподібна, півмісяцева кістки. АВН спостерігається у 1-10\% пацієнтів, яким проводилась хіміотерапія лімфом 3 високими дозами глюкокортикоїдів і більш ніж у $10 \%$ пацієнтів, які приймали імуносупресивну терапію після трансплантації кісткового мозку [2]. Нерідко виникнення АВН спостерігається при деяких ревматологічних захворюваннях, наприклад, ревматоїдному артриті.

Серед пацієнтів, яким проводилась променева терапія з приводу злоякісних новоутворень органів малого таза, $\mathrm{ABH}$ - відносно рідкісний прояв пізніх променевих реакцій. Причина його виникнення - прогресуючий променевий васкуліт з проліферацією ендотелію мікроциркуляторних судин, фіброзом, блоком артеріального припливу і венозного відтоку від ураженої ділянки кісткової тканини, що супроводжується підвищенням інтрамедулярного тиску і порушенням перфузії, а надалі проявляється некрозом ураженої ділянки кісткового мозку. У цій роботі ми представляємо клінічний випадок аваскулярного некрозу лівої латеральної маси крижів як прояв пізньої променевої реакції у пацієнта, який отримав курс хіміопроменевої терапії з приводу первинного місцево поширеного раку прямої кишки і досяг стану повного клініко-радіологічного регресу.

\section{ПРЕЗЕНТАЦІЯ КЛІНІЧНОГО ВИПАДКУ}

Пацієнт К., 75 років. Вважає себе хворим з осені 2016 року, коли вперше помітив виділення крові з випорожненням. Лікувався симптоматично. Через появу болю під час дефекації звернувся за медичною допомогою. За місцем проживання виявлено новоутворення прямої кишки. Для обстеження і лікування

\section{INTRODUCTION}

Bone complications after radiation therapy of malignant tumors occur in almost $30 \%$ of patients, although they correspond to delayed radiation effects. Most commonly bone complications are developed among those who underwent radiation therapy for pelvic malignancies, such as cervical $(65.6 \%)$, rectal $(18 \%)$, bladder $(10.7 \%)$ and endometrial $(5.7 \%)$ cancer [1].

Avascular necrosis, also known as bone marrow infarction, develops due to a critical ischemia which results in a lack of microcirculatory perfusion of the former. Such condition is common for bones which have a blood supply with terminal branches of concomitant major vessels and therefor have an underdeveloped routes of collateral blood flow. Femoral head, proximal epimetaphys of tibia and humerus, talus, scaphoideal and semilunar bones are mostly affected. Avascular necrosis occurs in 1-10\% of lymphoma patients treated with chemotherapy and high doses of glucocorticoids. It is also observed in more then $10 \%$ of patients receiving immunosuppressive therapy after bone marrow transplantation [2]. A number of benign systemic diseases, such as rheumatoid arthritis, often present with avascular necrosis as well.

Nevertheless, for patients after pelvic radiation therapy avascular necrosis is a remarkably rare condition. For these patients the main reason for development of avascular necrosis is a progressing radiation vasculitis with concomitant fibrotic substitution of endothelial lining, blockade of inflow and outflow at the site of bone tissue lesion, which consequently causes bone marrow ischemia, intramedullary hypertension and necrosis of the involved bone marrow region later on down the line. We present a rare case report of a bilateral avascular necrosis of lateral sacral masses as a late radiation effect in a patient who developed a sustainable complete clinical and radiological response after chemoradiotherapy for locally advanced rectal cancer.

\section{CASE PRESENTATION}

Patient K., 75 years old. Considers himself sick since the fall of 2016, when he first noticed the discharge of blood with a defecation. He was treated symptomatically. Because of pain during bowel movement, he sought medical help. The neoplasm of rectum was disgnosed at a local healthcare institution. For 
спрямований у відділення онкоколопроктології Національного інституту раку. При тотальній колоноскопії визначалося екзофітне пухлинне утворення м’якоеластичної консистенції, ригідне в основі, помірно рухоме, розташоване за 6-10 см від анального краю, що займало практично увесь просвіт прямої кишки.

Ендоскопічно інших новоутворень не було виявлено. Заключення щипцевої біопсії - елементи високодиференційованої аденокарциноми.

За даними комп'ютерної томографії органів грудної, черевної порожнин і порожнини малого таза з внутрішньовенним контрастним посиленням, метастатичного ураження апікальних і парааортальних лімфовузлів, а також віддалених метастазів, не виявлено. Стандартні лабораторні аналізи (загальний аналіз крові, сечі, біохімічний аналіз крові, коагулограма), а також показники онкомаркерів СА 242 і PEA - без істотних відхилень. Для локального стадіювання виконано магнітно-резонансну томографію (МРТ) органів малого таза. Дослідження проведене на апараті Philips Intera 1,5 T відповідно до протоколу MERCURY.

На серії сагітальних, аксіальних і напівкоронарних (паралельно поздовжній осі мезоректума) МРТсканів визначалась екзофітна пухлина середньомпулярного відділу прямої кишки до 68 мм в найбільшому вимірі (рис. 1А, фіолетовий пунктир). На передній поверхні визначалась інвазія мезоректальної клітковини з інфільтрацією фасції Денонвільє з позитивним радіологічним циркулярним краєм, розмір якого склав 1,77 мм (рис. 1А, зелені стрілки, червоні хрести; рис. 1В, жовті стрілки). Максимальна глибина мезоректальної інвазії за даними аксіальних сканів склала 16 мм, що відповідало ступеню поширеності mrT3c (рис. 1B). Даних про ураження регіонарних лімфатичних вузлів, а також про екстрамуральну судинну інвазію (EMVI) не отримано. На серії дифузно зважених МРТ-зображень упроекції пухлини, що візуалізується, визначалося виражене підвищення сигналу при високих b-чинниках, а також обмеження дифузії на ІКД-карті (рис. 1С, червоний пунктир).

На підставі отриманих клінічних, радіологічних і патогістологічних даних, пацієнтові встановлено клінічний діагноз: «місцево поширений рак середньоампулярного відділу прямої кишки mrT3c mrN0 сM0 mrEMVI-, mrCRM+». Мультидисциплінарною комісією прийнято рішення про проведення курсу неоад’ювантної хіміопроменевої терапії в сумарній дозі 50,4 Гр, разова доза - 1,8 Гр упродовж 5 тижнів паралельно з двома курсами поліхіміотерапіі за схемою XELOX: оксалиплатин 130 мг/м² в перший день, капе- examination and treatment, he was referred to the Department of Oncology and Cancer of the National Cancer Institute. In total colonoscopy, exophytic tumor formation of a softly elastic consistency, rigid at the base, moderately motile, located $6-10 \mathrm{~cm}$ from the anal edge, which occupied almost the entire lumen of the rectum, was determined.

Snare biopsy was taken from a rectal lesion, showing signs of highly differentiated adenocarcinoma.

A CT scan with intravenous enhancement of the chest, abdomen and cavity of the lesser pelvis showed no signs of neither distant metastases neither thoracic or intraabdominal lymphadenopathy. Laboratory data of standard blood, serum and urine counts, coagulation profile assay («coagulogram»), CA 242 and CEA revealed no signs of pathology. Consecutively a pelvic MRI with 1.5 Tl Philips Intera machine had been performed for local staging. MERCURY protocol for high resolution imaging was applied.

On a series of sagittal, axial and semi-coronal scans (along the mesorectum long axis) a mid rectum exophytic tumor with maximum dimension of $68 \mathrm{~mm}$ had been observed (see fig. 1A, purple dotted line). Anteriorly a mesorectal invasion with Denonvillier's fascia infiltration together with a threatened circumferential margin of $1.77 \mathrm{~mm}$ was detected (see figure 1A, green arrows, red crosses and figure 1B, yellow arrows). Maximal depth of mesorectal invasion ranged up to $16 \mathrm{~mm}$, corresponding to mrT3c level of spread (figure 1B). No radiological signs of extramural vascular invasion (mrEMVI-) were observed. Visible mesorectal lymph nodes had homogenous MR signal, smooth external margins and regular size, thus showing no radiologic signs of lymph node involvement (mrN0). Malignant tumor features were also observed on a series of diffusion weighted images (Fig. $1 \mathrm{C}$, red dotted line).

Regarding clinical findings, radiologic, endoscopic and pathologic data, the patient was initially diagnosed with a locally advanced cancer of the mid rectum and staged as mrT3c mrNo cM0 mrEMVI-, mrCRM+. An institutional multidisciplinary board suggested to provide a neoadjuvant course of chemoradiation therapy with overall dosage of $50.4 \mathrm{~Gy}$ and a fraction dosage of $1.8 \mathrm{~Gy}$ during 5 weeks together with two concomitant courses of neoadjuvant 


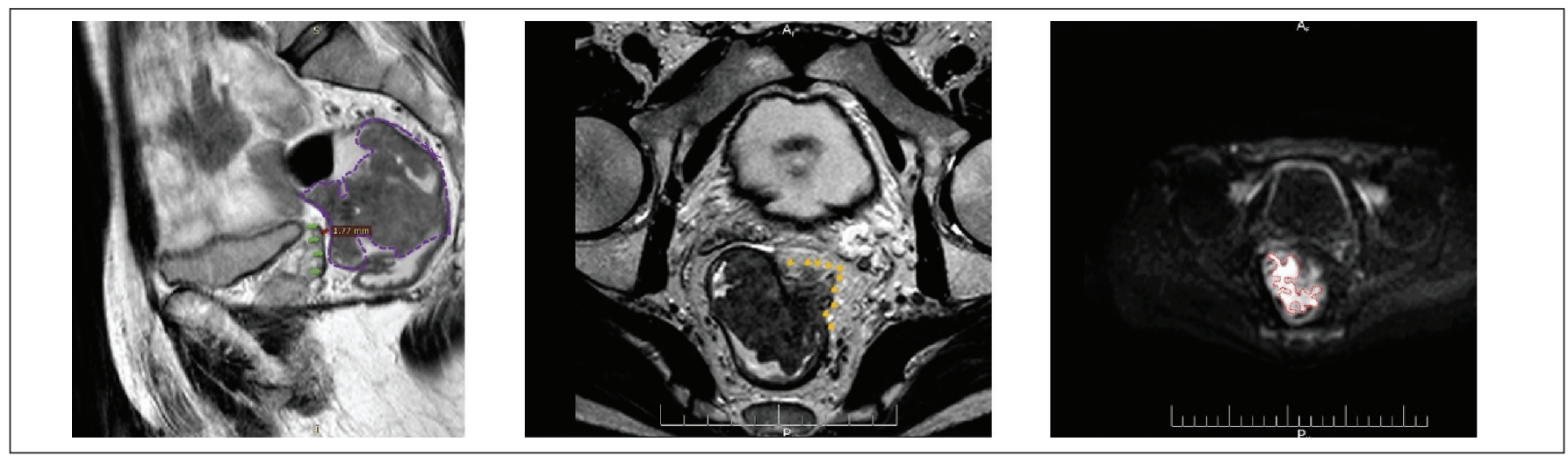

\section{Рисунок 1. МРТ стадіювання до початку неоад'ювантної хіміопроменевої терапії}

На серії сагітальних сканів (рис. 1А) візуалізується пухлина середньоампулярного відділу прямої кишки (фіолетовий пунктир) зрадіологічними ознаками мезоректальної інвазії, інфільтрації фасції Денонвільє (зелені стрілки), що відповідає позитивному радіологічному циркулярному краю (червоні хрести). Глибина мезоректальної інвазії впроекції основи пухлини на серії аксіальних сканів (рис. 1В, жовті стрілки) склала 16 мм. На серії дифузно зважених зображень (рис. 1С) відмічено значне уповільнення дифузії в проекції основи пухлини (червоний пунктир).

\section{Figure 1. Radiologic data from a high-resolution pelvic MRI prior to neoadjuvant chemoradiation therapy}

On a series of sagittal scans (1A) a mid rectal tumor (violet dashed line) with radiological signs of both mesorectal invasion and Denonvillier's fascia infiltration (green arrowheads) with a threatened radiologic circumferential margin (red crosses). On a series of axial scans the depth of mesorectal invasion ranged up to $16 \mathrm{~mm}$ (1B, yellow arrowheads). On a series of diffusion weighted images (1C) a significant delay of diffusion together with intense signaling on high b-factors was observed at the level of a tumor basis (red dashed line).

цитабін 2500 мг/м² з 1-го по 14-й день, з 15-го по 21-й день - перерва. Курс променевої терапії проводили на лінійному прискорювачі електронів VARIAN Clinac $2100 \mathrm{C} \backslash \mathrm{D}$ енергією фотонів $6 \mathrm{Mv}$. У топометричній підготовці використовували спіральний комп'ютерний томограф PHILIPS Brilliance CT Big Вore з системою лазерного визначення ізоцентру планованого об’єму LAP Laser. Для максимального підвищення точності положення пацієнта були використані фіксувальні термопластичні маски Orfit. Планування опромінення проводили на системі VARIAN Eclipse по 3d методиці. У зону опромінення входила безпосередньо пряма кишка (GTV) із захопленням мезоректальної клітковини (CTV 1 см $\operatorname{lng} 2$ см) і шляхів регіонарного лімфовідтоку. Для точного визначення опромінюваного обсягу було використано МРТ дослідження з контрастним підсиленням і подальшим зіставленням з отриманим раніше при топометричній підготовці зображенням спіральної комп'ютерної томографії.

При плануванні курсу дистанційної променевої терапії брали до уваги два основних принципи, а саме: максимальне покриття дозою планованого обсягу опромінення і максимальне зменшення дози на критичні органи. До критичних органів відносили: сечовий міхур, лівий і правий тазостегновий суглоби, передміхурову залозу і спинний мозок. Контроль розподілу дози проводився за критерієм 90 \% дози в планованому обсязі опромінення. У процесі сеансу дистанційно-променевої терапії здійснювали конт- chemotherapy using a CapOX regimen. Radiation therapy had been carried out with a VARIAN «Clinac $2100 \mathrm{C} \backslash \mathrm{D}$ » electron linear accelerator with photon energy of $6 \mathrm{Mv}$. For topometric preparation a spiral computed tomograph PHILIPS «Brilliance CT Big Bore» with a «LAP Laser» system for definition of a target volume isocenter was used. To achieve maximal precision of patient's positioning an «Orfit» thermoplastic masks were applied. A 3D conformal radiation therapy was performed with the use of VARIAN «Eclipse» hardware. The radiation field included the rectum itself (GTV) covering also mesorectum $(\mathrm{CTV}+1 \mathrm{~cm} . \operatorname{lng}+2 \mathrm{~cm})$ and possible routes of lymphatic spread. To achieve a more precise target volume distribution a comparison of contrasted pelvic MRI with previously obtained topometric CT scans was used.

Two basic principles have been taken into account when planning the course of distance radiation therapy, namely the maximal coverage of a planned radiation field with minimal irradiation of adjacent critical organs was carried out as well. As critical organs the urinary bladder, right and left coxofemoral joint, prostate and spinal cord were identified. Dose distribution control was achieved by a criteria of $90 \%$ isodose in a target volume. During radiation therapy the 
роль фактичного положення пацієнта за допомогою системи портальної візуалізації Varian Portal Vision. Курс хіміопроменевої терапії був перенесений задовільно, без істотних клінічних проявів токсичності. 3 метою максимальної реалізації ефекту хіміопроменевої терапії інтервал від завершення до повторного стадіювання склав 12 тижнів.

Під час контрольного МРТ дослідження через 12 тижнів після завершення курсу хіміопроменевої терапії на серії сагітальних сканів виявлена нормальна структура стінки прямої кишки, без візуальних ознак пухлини. Раніше візуалізована зона інфільтрації фасції Денонвільє змезоректальною інвазією і позитивним циркулярним радіологічним краєм представлена тканиною $з$ дещо посиленим МР-сигналом за рахунок інтерстиціального постпроменевого набряку (рис. 2А). Перехідна складка очеревини, фасція Денонвільє мали типову радіологічну структуру. Зона мезоректальної інвазії, візуалізована раніше на серії аксіальних сканів, заміщена фіброзною тканиною з ознаками інтерстиціального набряку (рис. 2В). На дифузно зваженому зображенні ділянки зниженої дифузії відзначалися лише в зоні слизової оболонки і підслизового шару, що за результатами зіставлення з клінічними і ендоскопічними даними, відповідало радіологічним симптомам пізнього променевого ректиту у фазі ремісії. Радіо- continuous control of patient's positioning was achieved by applying Varian Portal Vision system. Both courses of chemotherapy were uneventful, without clinically significant signs of toxicity. In an attempt to achieve maximum response rate, a 12 week observation period was selected.

In 12 weeks after chemoradiotherapy a complete clinical and radiological response was observed at the schedulled MRI session. High definition pelvic MRI revealed a normal structure of the rectal wall without visible tumor sites mentioned previously. Regions of mesorectal invasion and Denonvillier's fascia infiltration with a positive circumferential margin were represented by a slightly enhanced signal due to an interstitial edema (Fig. 2). Peritoneal reflection and mesorectal fascia had regular radiological structure. On a series of axial scans tumor infiltration of the mesorectum was substituted with swollen fibrotic tissue. A series of diffusion weighted images revealed a delay of diffusion limited by mucosa and submucosa, which corresponded with clinical and endoscopic data suggesting for a complete tumor response accompanied by mild radiation proctitis. No radiologic
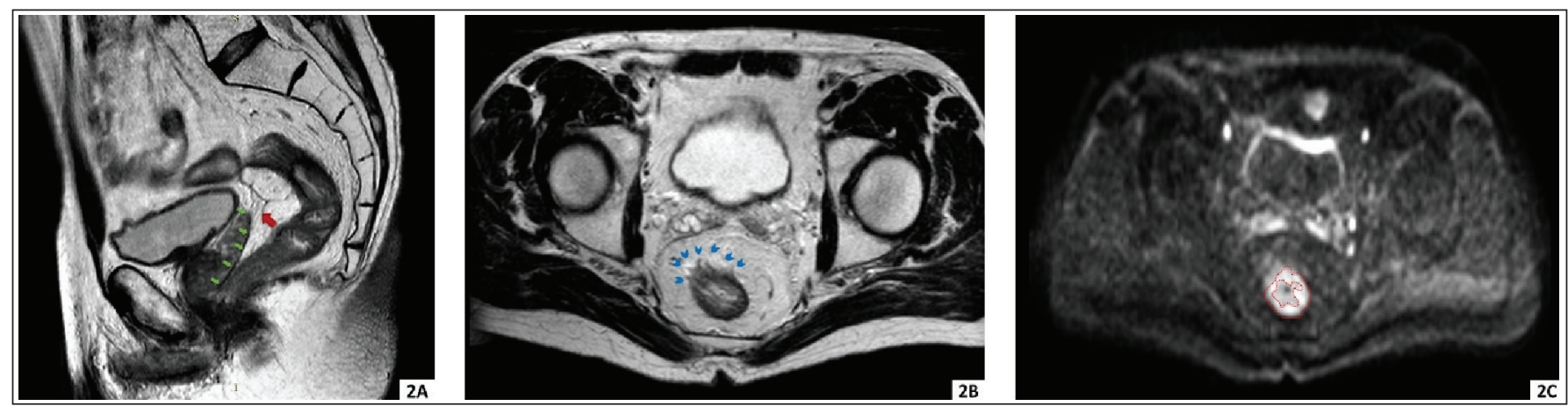

Рисунок 2. МРТ рестадіювання через 12 тижнів після завершення хіміопроменевої терапії

Відзначається нормальна структура шарів прямої кишки, а пухлина, що раніше візуалізувалась, не визначається. Фасція Денонвільє (рис. 2А, зелені стрілки) не змінена. Зона мезоректальної інвазії, що раніше візуалізувалась, з формуванням позитивного циркулярного радіологічного краю (рис. 2А, червона стрілка) представлена фіброзною тканиною з дещо посиленим МР-сигналом за рахунок інтерстиціального набряку. На серії аксіальних сканів мезоректальна фасція цілісна на усьому протязі, зона інфільтрації мезоректальної клітковини, що раніше візуалізувалась, заміщена фіброзною тканиною з ділянками гіперінтенсивного МР-сигналу за рахунок інтерстиціального постпроменевого набряку (рис. 2В, сині стрілки). На серії дифузно зважених зображень зберігаються ділянки зниженої дифузії в зоні слизової оболонки іпідслизового шару (рис. 2С, подвійний червоний пунктир), розцінені при зіставленні з клінічними і ендоскопічними даними як радіологічний симптом пізнього променевого ректиту у фазі ремісії.

\section{Figure 2. MRI restaging in 12 weeks after completion of chemoradiation therapy}

Normal structure of the rectal wall without any signs of tumor deposits was observed. Denonvillier's fascia (2A, green arrowheads) has its regular structure. Previously identified mesorectal invasion with a threatened circumferential margin (2A, red arrowhead) is represented by fibrotic tissue with slightly enhanced MR signal due to an interstitial edema. Axial scans demonstrate the integrity of an entire circumference of mesorectal fascia. Previously visualized region of mesorectal infiltration is substituted by swollen fibrotic tissue also carrying signs of postradiation edema (2B, blue arrowheads). Diffusion weighted images reveal a slight delay of diffusion at the level of rectal mucosa and submucosa ( $2 \mathrm{C}$, red dashed line), which corresponded with clinical and endoscopical findings suggesting for a complete tumor response accompanied by mild radiation proctitis. 


\section{КЛІНІЧНА

логічних ознак метастатичного ураження регіонарних лімфатичних вузлів за даними МРТ не виявлено.

Результати повторної спіральної комп'ютерної томографії органів грудної, черевної порожнин і малого таза з внутрішньовенним контрастним підсиленням підтвердили відсутність віддалених метастазів. При контрольному ендоскопічному дослідженні (фіброколоноскопія) пухлина, що раніше візуалізувалась, заміщена рубцевою тканиною, навколишня слизова оболонка - з ознаками пізнього постпроменевого ректиту у фазі ремісії (рис. 3). На підставі клінічних, ендоскопічних і радіологічних даних ступінь відповіді на хіміопроменеву терапію розцінена як повний клініко-радіологічний регрес первинної пухлини.

В якості подальшої онкологічної тактики, враховуючи ступінь відповіді на хіміопроменеву терапію і побажання пацієнта, була обрана стратегія активного спостереження (Watch \& Wait), що передбачає радіологічний іендоскопічний контроль (МРТ малого таза і ректороманоскопія) що 3 місяці з метою своєчасного виявлення продовження росту первинної пухлини.

На момент першого контрольного дослідження (через 24 тижні після завершення неоад’ювантної хіміопроменевої терапії) у пацієнта виникли скарги на біль в ділянці лівого тазостегнового суглоба під час ходьби іфізичних навантажень. Під час контрольного МРТ виявлені ознаки аваскулярного некрозу лівої латеральної маси крижів, лівобічного сакроїлеїту, яких не відзначалося при первинному стадіюванні (рис. 4). signs of lymph node involvement haven't been observed as well.

Repeated session of the computed tomography of chest, abdomen and cavity of the lesser pelvis with intravenously administered contrast enhancement confirmed no signs of distant metastases. Lower GI endoscopy (fibrocolonoscopy ) revealed a flat white scar at the previous tumor site together with signs of mild radiation proctitis of the surrounding mucosa (Fig. 3). By taking in regard both clinical and radiologic data together with additional endoscopic findings as well, a diagnosis of a complete tumor response had been carried out.

As a further oncology tactic, considering the degree of response to chemotherapy and patient's wishes, a strategy of active observation (Watch \& Wait) was chosen, providing for radiological and endoscopic control (MRI of the pelvis and rectomethanoscopy) every 3 months with a view to timely detection of continuation of growth of primary tumor.

At the time of the first follow-up examination (24 weeks after the completion of neoadjuvant chemotherapy), the patient had emerged complaints of pain in the left hip while walking and physical exertion. During the control MRI, signs of avascular necrosis of the left lateral mass of sacrum, left-sided sacroiliitis, which were not noted during the initial stage (Fig. 4), were revealed.

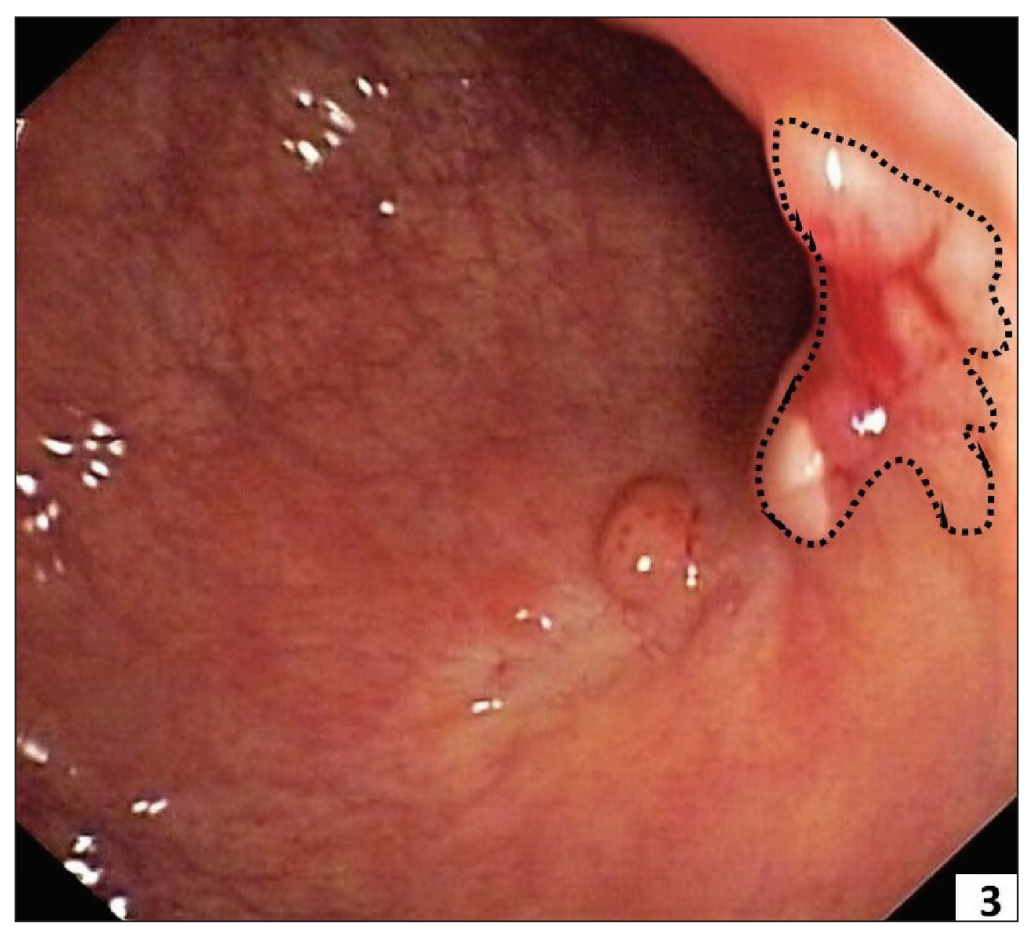

Рисунок 3. Ендоскопічна картина через 12 тижнів після завершення хіміопроменевої терапії

Зона екзофітної пухлини, що візуалізувалась раніше, представлена білястим рубцем (чорний пунктир) в оточенні телеангіоектазій і гіперпластичного поліпа, який, за даними щипцевої біопсії, був представлений грануляційною тканиною. Слизова оболонка, що оточує рубець, помірно гіперемована, згладжена, з вираженим судинним малюнком, без конвергенції складок.

Figure 3. Endoscopic reassessment in $\mathbf{1 2}$ weeks after chemoradiotherapy completion Previously observed exophytic tumor mass is replaced by a flat white scar (black dashed line) with a number of surrounding teleangiectases and a hyperplastic polyp, which consisted of granulation tissue according to snare biopsy data. The surrounding mucosa has signs of mild hyperemia, swelling and a visible vasculature picture, but without of convergence. 

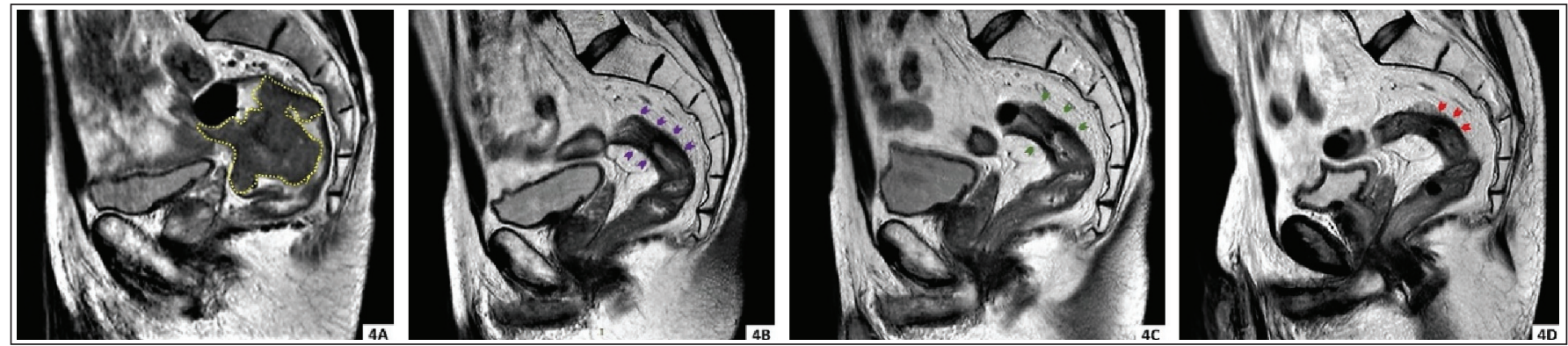

Рисунок 4. Динаміка локального контролю первинної пухлини після завершення хіміопроменевої терапії Місцево поширена пухлина прямої кишки (рис. 4А, жовтий пунктир) через 12 тижнів після завершення хіміопроменевої терапії не визначається. Відзначається нерівномірне потовщення стінок прямої кишки (рис. 4B-D) за рахунок вираженого постпроменевого фіброзу (рис. 4В, фіолетові стрілки). Через 24 тижні після завершення неоад'ювантного лікування структура стінок прямої кишки набула великої виразності зі збереженням потовщення тільки по задній напівокружності (рис. 4С, зелені стрілки). Через 2 роки після завершення лікування єдина МР-ознака попередньої хіміопроменевої терапії - декілька ділянок з гіперінтенсивним сигналом від вогнищ мезоректального склерозу (рис. 4D, червоні стрілки).

\section{Figure 4. A 2-year radiologic surveillance data after completion of chemoradiation therapy}

Primary locally advanced mid rectal tumor (4A, yellow dashed line) was unidentified in 12 weeks after chemoradiotherapy. Previous tumor site is represented as irregular thickening of a rectal wall (4B-D) due to development of postradiation fibrosis (4B, violet arrowheads). In 24 weeks after chemoradiotherapy completion the structure of rectal walls became more regular with local thickening only at the posterior wall (4C, green arrowheads). In 2 years after treatment the only noticeable radiologic feature of postradiation fibrosis was represented by a couple of sites of mesorectal sclerosis (4D, red arrowheads).
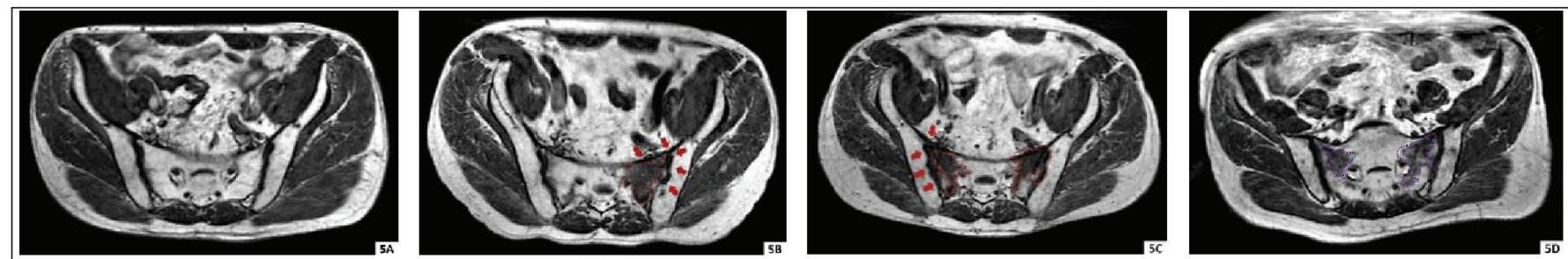

Рисунок 5. Радіологічна динаміка кістково-деструктивних зміну того самого пацієнта

На момент встановлення діагнозу патології з боку кісток осьового скелета не відзначалося (рис. 5 A). Через 24 тижні після завершення променевої терапії на Т1 зваженому зображенні відмічено вогнище аваскулярного некрозу лівої латеральної маси крижів (рис. 5В, червоний пунктир) з ознаками лівобічного сакроїлеїту - розширення суглобової щілини, періостальний набряк (рис. 5В). Через 36 тижнів після завершення хіміопроменевої терапії - аналогічне вогнище аваскулярного некрозу, візуалізоване в обох латеральних масах крижів (рис. 5С, червоний пунктир), з ознаками двостороннього сакроїлеїту (рис. 5С, червоні стрілки). Через 2роки після завершення хіміопроменевої терапії площа уражених латеральних мас крижів зменшилася (рис. 5D, фіолетовий пунктир), відзначаються ділянки реорганізації кісткової тканини.

\section{Figure 5. Radiologic signs of sacral lesions at the same patient}

At the moment of initial diagnosis no signs of pelvic bone pathology were observed (5A). In 24 weeks after completion of chemoradiation therapy a focus of left lateral sacral mass avascular necrosis was identified on a series T1-weighted images (5B, red arrowheads). Additional signs of sacroilitis, such as periosteal edema and distensibility of the articulary cavity, were also detected. In 36 weeks after completion of chemoradiation therapy a similar lesion was observed in both lateral sacral masses (5C, red dashed line) with signs of concomitant bilateral sacroilitis (5C, red arrowheads). In 2 years after treatment completion the area of previously described sacral lesions had diminished (5D, violet dashed line) with fibrotic substitution and sites of bony tissue reorganization.

Водночас радіологічна картина відповідала повному клініко-радіологічному регресу первинного місцево поширеного раку прямої кишки, що підтверджувалося також даними спіральної комп'ютерної томографії відносно віддалених метастазів (рис. 5). Для диференційної діагностики метастатичного ураження кісток осьового скелета пацієнтові була виконана остеосцинтиграфія із застосуванням ${ }^{99} \mathrm{Tc}$. Знижений відносно норми рівень накопичення радіофармпрепарату у вказаній ділянці крижів свідчив на користь
At the same time, the radiological pattern corresponded to the complete clinical and radiological regression of primary locally advanced rectal cancer, which was also confirmed by the data of spiral computed tomography with respect to distant metastases (Fig. 5). For differential diagnosis of metastatic bone lesions of the axial skeleton, the patient underwent osteoscintigraphy using ${ }^{99} \mathrm{Ts}$. The reduced level of accumulation of the radiopharmaceutical relative to the norm in the specified area of the sacrum testified 
його неспецифічного ураження. Після проведеного лікування стан пацієнта покращав, больовий синдром під час ходьби і фізичних навантажень зменшився, пацієнтові продовжена тактика активного спостереження за програмою Watch \& Wait. Через 6 міс. після завершення хіміопроменевої терапії, під час другого контрольного дослідження, виявлена ділянка аваскулярного некрозу правої латеральної маси крижів, з радіологічною картиною аналогічною попередній. На відміну від раніше спостережуваного, це ураження крижів мало безсимптомний перебіг.

На момент опису наведеного клінічного випадку період активного спостереження склав 2 роки 3 моменту завершення хіміопроменевої терапії. Стан пацієнта задовільний, при контрольному обстеженні даних за пухлинну прогресію не отримано.

\section{ДИСКУСІЯ}

Променева терапія - невід'ємна складова комбінованого лікування не лише раку прямої кишки, але й інших онкологічних нозологій малого таза. Увипадках не лише місцево поширеного, але також i «раннього» раку прямої кишки, неоад’ювантна променева терапія може індукувати як значну часткову, так i повну регресію первинної пухлини, забезпечуючи при цьому прийнятний безрецидивний період [3-5].

За нашими 3-річними об'єднаними даними, серед 57 пацієнтів з місцево поширеним раком прямої кишки, які отримували неоад'ювантну хіміопроменеву терапію за наведеною схемою, тільки в одного розвинувся такий рідкісний ефект, як двосторонній аваскулярний некроз латеральних мас крижів. Серед пацієнтів було $22(38,6 \%)$ жінки і $35(61,4 \%)$ чоловіків віком від 23 до 77 років, в середньому $(59,3 \pm 1,5)$ року. Індекс маси тіла (IMT) в середньому склав

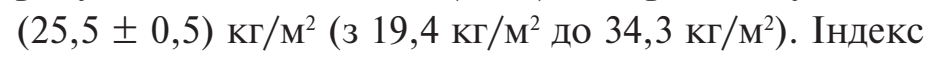
супутньої патології Чарльсона 0 мали $13(22,8 \%)$ пацієнтів, 1 бал - 15 (26,3\%), 2 бали - 19 (33,3\%), 3 бали - $9(15,8 \%), 4$ бали - 1 (1,8\%). Розподіл хворих відповідно до критерію індексу сTNM узагальнений в таблиці 1.

Разом з тим відомо, що у значної частини цих пацієнтів будуть ускладнення або побічні ефекти променевої терапії, що дуже часто важко піддаються лікуванню [6]. За даними більшості авторів, у $90 \%$ пацієнтів після тривалих курсів хіміопроменевої терапії зберігається персистувальна диспепсія, $50 \%$ відмічають стійке погіршення якості життя, з яких 20-30\% оцінюють його рівень нижчим за середній показник [7, 8]. У більшості пацієнтів домінуючими симптомами, які можуть виникати упродовж від 2 міс. in favor of a nonspecific nature of the lesion. After the treatment, the patient's condition improved, the pain during walking and exercise decreased, the patient continued tactics of active observation according to the Watch \& Wait approach. During the second control study 6 months upon completion of chemoradiation therapy a site of avascular necrosis of the right lateral mass of the sacrum was revealed with a radiological picture similar to the previous one. Unlike previously observed, this lesion of the sacrum had an asymptomatic course.

At the time of presentation of this clinical case, the period of active observation was 2 years from the end of chemotherapy. The patient's condition is satisfactory, no control data were obtained for tumor progression.

\section{DISCUSSION}

Radiation therapy is an integral part of the combined treatment of not only rectal cancer, but also other malignancies of a cavity of the lesser pelvis. In cases of both locally advanced and «early» rectal cancer, neoadjuvant radiation therapy can provide major and complete tumor response, while ensuring an acceptable recurrence-free period [3-5].

According to our 3-year pooled data, among 57 patients with locally advanced rectal cancer treated by neoadjuvant chemoradiation therapy of the same regimen, only one developed such a rare effect as bilateral avascular necrosis of sacral lateral masses. Among the patients, there were $22(38.6 \%)$ women and $35(61.4 \%)$ men aged 23 to 77 years, with an average of $59.3 \pm 1.5$ years. The body mass index (BMI) averaged $25.5 \pm 0.5 \mathrm{~kg} / \mathrm{m}^{2}$ (from $19.4 \mathrm{~kg} / \mathrm{m}^{2}$ to $34.3 \mathrm{~kg} / \mathrm{m}^{2}$ ). The Charlson Comorbidity Index 0 had $13(22.8 \%)$ patients, 1 point $15(26.3 \%), 2$ points $19(33.3 \%), 3$ points 9 $(15.8 \%), 4$ points $-1(1.8 \%)$. The distribution of patients in accordance with the criterion of the cTNM index is given in Table 1.

However, it is known that a significant proportion of patients exposed to pelvic irradiation will have complications or side effects of radiation therapy, which are often difficult to treat [6]. According to most authors, ninety percent of patients who underwent chemoradiation therapy experience persistent dyspepsia, $50 \%$ also report a deterioration in the quality of life, of which 20-30\% rate it below the average [7, 8]. In most patients, the combination of diarrhea, rectal bleeding and 


\section{Таблиця 1}

Розподіл хворих з первинним місцево поширеним раком прямої кишки, які отримували неоад'ювантну хіміопроменеву терапію, за стадіями

\section{Table 1}

Distribution of patients with primary locally advanced rectal cancer treated by neoadjuvant chemoradiation therapy by stage

\begin{tabular}{|c|c|c|}
\hline $\begin{array}{l}\text { Критерій індексу стNM } \\
\text { cTNM staging }\end{array}$ & $\begin{array}{c}\text { Кількість, } \mathbf{n} \\
\text { Absolute number }\end{array}$ & $\%$ \\
\hline $\mathrm{cT}_{3 \mathrm{c}} \mathrm{N}_{0}$ & 17 & 29,8 \\
\hline $\mathrm{CT}_{3 \mathrm{c}} \mathrm{N}_{1}$ & 3 & 5,3 \\
\hline $\mathrm{cT}_{4 \mathrm{c}} \mathrm{N}_{0}$ & 6 & 10,5 \\
\hline $\mathrm{CT}_{4 \mathrm{c}} \mathrm{N}_{1}$ & 3 & 5,3 \\
\hline $\mathrm{CT}_{3} \mathrm{~N}_{2}$ & 17 & 29,8 \\
\hline $\mathrm{CT}_{4} \mathrm{~N}_{2}$ & 11 & 19,3 \\
\hline CRM + & 57 & 100,0 \\
\hline $\mathrm{EMVI}+$ & 22 & 38,6 \\
\hline
\end{tabular}

до 30 років після завершення променевої терапії на ділянку малого таза, залишаються поєднання діареї, ректальної кровотечі і больового синдрому [9].

Попри те, що основна доза іонізуючого випромінювання проектується іспрямовується на цільовий орган, суміжні критичні органи, в першу чергу всі органи малого таза і термінальні відділи клубової кишки, також отримують певну дозу опромінення, яка індукує розвиток основних проявів гастроінтестинальної токсичності променевої терапії. Зважаючи на різну гістологічну будову критичних органів малого таза, їх різну радіочутливість, регенераторний потенціал, розподіл і фракціонування дози опромінення, нелінійність альтерації проведеною променевою терапією, спонукало J. Andreyev зі співавт. до введення поняття «тазова променева хвороба (pelvicradiation disease)» [10].

У рамках цієї концепції, залежно від переважання цитотоксичної альтерації при ранній фазі запалення або інтерстиціального склерозу зваскулітом мікроциркуляторних судин, ускладнення променевої терапії розподіляють на ранні (до 12 тижнів від початку променевої терапії) і пізні (більше 12 тижнів від початку променевої терапіі).

Чинники ризику розвитку ускладнень променевої терапії, згідно зконцепцією J. Andreyev зі співавт., розподіляються на залежні від пацієнта і від способу променевої терапії. До перших відносять наявність цукрового діабету (ризик променевого проктиту на $28 \%$ вищий), паління, запальні захворювання товстої кишки в анамнезі (на 29-46 \% вищий ризик розвитку усіх ускладнень), системні захворювання сполучної тканини в анамнезі, раніше перенесені оперативні втручання на органах черевної порожнини або малого таза (можливість фіксації тонкої кишки pain syndrome remains as the dominant symptoms that can occur for 2 months to 30 years after the completion of pelvic radiation therapy [9].

Despite the fact that the main dose of ionizing radiation is delivered and directed to the target organ, adjacent critical organs, first of all the pelvic organs and terminal ileum, also receive a certain dose of radiation that induces the development of the main manifestations of gastrointestinal toxicity of radiation therapy. Taking in regard the different histological structure of the critical pelvic organs, their different radiosensitivity, regenerative potential, distribution and fractioning of the radiation dose, the «nonlinearity» of the alteration carried out by radiation therapy, J. Andreyev et al. has recently come up with a «pelvic radiation disease» concept [10].

Within this concept, depending on the predominance of cytotoxic alteration during the early phase of inflammation or delayed sclerosis with microvascular vasculitis, the complications of radiation therapy were divided into early (up to 12 weeks from the start of radiation therapy) and late (more than 12 weeks from the start of radiation therapy).

The risk factors for the development of radiation therapy complications, according to the concept of J. Andreyev et al., are divided into patient related and radiation therapy related. The former includes the presence of diabetes mellitus (the risk of radiation proctitis is $28 \%$ higher), smoking, past history of inflammatory bowel disease (29-46 \% higher risk of developing all complications), history of systemic diseases of connective tissue, previous surgical interventions on either abdominal or pelvic organs (the possibility of fixation of the small intes- 
спайками до поля опромінення), а також як високий, так і низький індекс маси тіла [10, 11]. Чинники ризику, пов'язані з лікуванням, - це передусім співвідношення дози, фракціонування і розміру поля опромінення. Другорядне значення має паралельний прийом хіміопрепаратів, а також таргетних препаратів, що впливають на ангіогенез [11].

Гострі прояви токсичності можуть виникати з боку будь-якого органа, що входить в поле променевої терапії, але насамперед це пряма ісигмоподібна кишки. Попри те, що перші симптоми променевого ушкодження вказаних органів, як правило, різноманітні і неспецифічні, убільшості випадків маніфестація настає через 2-3 тижні від початку курсу і досягає найбільшої вираженості на 4-5-й тиждень, при адекватному лікуванні припиняється через 3-9 міс. після завершення курсу [12]. Під час ранньої фази променевого ушкодження десквамація епітелію і його скупчення у просвіті крипт товстої кишки спостерігаються вже через 8 год. після дії іонізуючого випромінювання. До інших характерних ознак ушкодження вгострій фазі належать набряк підслизового шару, його інфільтрація епітеліоїдними клітинами і формування еозинофільних мікроабсцесів у його товщі.

Мітоз в неушкоджених епітеліоцитах істотно уповільнений, що веде до тривалої експозиції прилеглих структур кишкової стінки вмісту їі просвіту. Важливою особливістю альтерації в ранній фазі є інтактність судин мікроциркуляторного русла i оборотність процесу [10-12]. Патогенетична картина «гострого променевого коліту», описана вище, в 25 \% випадків доповнюється проявами променевого ентериту, для якого характерні надмірний ріст мікроорганізмів і, відповідно, бактерійна транслокація вдистальні відділи травного каналу [10, 12].

На відміну від гострих ушкоджень, гістологічні особливості хронічного ушкодження відрізняються значною мірою. Головним патогенетичним механізмом, що призводить до безповоротних морфологічних змін, в даному випадку є прогресуючий фіброз із залученням усіх шарів кишкової стінки або будь-якого іншого критичного органу [13]. У судинах мікроциркуляторного зростання на тлі променевого васкуліту розвиваються склероз і облітерація, що проявляються в першу чергу в атрофії епітелію слизової оболонки [10, 13]. Наростаюча ішемія веде до подальшого прогресу фіброзу, замикаючи таким чином «хибне коло». Індукована променевим васкулітом ендотеліальна дисфункція веде до підвище- tine by adhesions to the irradiation field), as well as both high and low body mass index [10, 11]. The risk factors associated with radiation therapy include the dose, fractioning and volume of the radiation field. Of paramount importance is the administration of concurrent chemotherapy, as well as targeted drugs that affect angiogenesis [11].

Acute toxicity can be related to any critical organ within the irradiation field, but first of all it is the rectum and sigmoid colon. Despite the fact that the first symptoms of radiation damage to these organs are usually diverse and nonspecific, in most cases manifestation occurs within 2 to 3 weeks from the start of the course and reaches its maximum intensity at 4 to 5 weeks. Under successful treatment it stops after 3 to 9 months following course completion [12]. During the early phase of radiation damage, desquamation of the epithelium and its accumulations in the lumen of the colon crypts are observed as early as 8 hours after exposure to ionizing radiation. Other significant signs of damage in the acute phase include edema of the submucosal layer, its infiltration with epithelioid cells and the formation of eosinophilic microabscesses in its thickness.

Mitosis in intact epithelial cells is significantly decreased, which leads to a long exposure of the underlying structures of the intestinal wall to the contents of its lumen. An important feature of alteration in the early phase is the intactness of the vessels of the microvasculature and the reversibility of the process [10-12]. The pathological features of «acute radial colitis» described above are supplemented in $25 \%$ of cases with manifestations of radiation enteritis, which is characterized by excessive growth of microorganisms and, consequently, bacterial translocation to the distal parts of the alimentary canal [10, 12].

Unlike acute lesions, the histological features of chronic lesion differ significantly. The main pathogenetic mechanism leading to irreversible morphological changes, in this case, is progressive fibrosis involving all layers of the intestinal wall or any other critical organ. [13]. Inside microcirculatory vessels sclerosis and obliteration develop on the background of radiation vasculitis, which are manifested primarily in atrophy of the mucous membrane epithelium [10, 13]. Increasing ischemia leads to further progression of fibrosis, thus closing the «vicious circle». Radiation induced vasculitis leads to endothelial dysfunction, causing increased expression of thrombin and 
ної експресії тромбіну і прозапальних простагландинів. Поєднання прогресуючого фіброзу, ішеміі і хронічного запалення призводять як до морфологічних, так і функціональних порушень.

Подібний патогенетичний механізм реалізації біологічного ефекту поглиненої іонізуючої енергії також характерний і для розвитку уражень кісткової тканини. Так, згідно з даними Ј. Hopewell зі співавт., непрямий ефект дії іонізуючого випромінювання на кісткову тканину полягає в патологічній зміні мікроциркуляторних судин кісткового мозку. Ангіофіброз імікроциркуляторна оклюзія супроводжуються тканинною гіпоксією, яка веде до скорочення кількості остеобластів, зниження синтезу колагену, лужної фосфатази, i, відповідно, до порушення мінералізації, що клінічно проявляється послідовністю дегенеративно-дистрофічних порушень іперелому [14]. У представленому клінічному випадку вперше описано дегенеративно-дистрофічну зміну кісткової тканини, що виникла на тлі реалізації повного клініко-радіологічного регресу первинного раку прямої кишки, з приводу якого проводилася хіміопроменева терапія.

Проблема радіаційного ушкодження кісток виникла одночасно зшироким застосуванням променевої терапії для лікування злоякісних новоутворень. Так, уперше термін «променевий остеїт» застосував J. Ewing у 1926 році для опису патогенетичного механізму спонтанного перелому ребер у пацієнток, які перенесли променеву терапію при раку молочної залози [15]. Незабаром, у 1942 році, L.Paul i W. Pohle встановили здатність іонізуючого випромінювання енергією 200 кіловольт ініціювати некроз кісткової тканини [16]. S. A. Guttenberg у 1972 році запропонував розрізняти поняття «асептичний остеорадіонекроз» $\mathrm{i}$ «інфікований остеорадіонекроз», що мають загальну етіологію, патогенез і патоморфологічні характеристики, але відрізняються відсутністю в першому або наявністю в другому випадку клінічної симптоматики [17]. 3 розвитком нових технічних форм променевої терапії змінились частота і ступінь тяжкості радіаційного ушкодження скелета. Уперше загальні закономірності променевого ушкодження кісток були продемонстровані в дослідженні W. Howland у 1975 році [18]. Незалежно від типу іонізуючого випромінювання, застосованого в групах (бета-випромінювання енергією 200 кіловольт, 25 МеВ і гамма-випромінювання від джерела $\left.{ }^{60} \mathrm{Co}\right)$, у всіх пацієнтів відзначалися рентгенографічна послідовність ущільнення трабекули, потовщення кортикального шару, локальної, а потім дифузної деміне- proinflammatory prostaglandins. The combination of progressive fibrosis, ischemia and chronic inflammation leads to both morphological and functional disorders.

A similar pathogenetic mechanism for the realization of biological effect of absorbed ionizing energy is also specific for the development of bone tissue lesions. Thus, according to J. Hopewell et al., the indirect effect of ionizing radiation on bone tissue is about a pathological change in the microvasculature of the bone marrow. Angiofibrosis and microcirculatory occlusion are accompanied by tissue hypoxia, which leads to a decrease in the number of osteoblasts, a decrease in the synthesis of collagen, alkaline phosphatase, and, consequently, to a violation of mineralization, which is clinically manifested by a sequence of degenerative and dystrophic disorders which result in fractures [14]. In the presented clinical case, a degenerative change in bone tissue of left lateral sacral masses was first described, which developed apart from a complete clinical and radiological response of primary rectal cancer.

The problem of radiation damage to the bone tissue arose simultaneously with the widespread use of radiation therapy for the treatment of malignant tumors. Thus, the term «radiation osteitis» was first used by Ewing in 1926 to describe the pathologic mechanism of spontaneous rib fracture in patients undergoing radiation therapy for breast cancer [15]. Soon, in 1942, Paul and Pohle established the ability of 200 kilovolts of ionizing radiation to initiate necrosis of bone tissue [16]. Guttenberg in 1972 proposed to separate the concepts of «aseptic osteoradionecrosis» and «infected osteoradionecrosis» that have a common etiology, pathogenesis and pathological characteristics, but differ by the mean of absence of clinical symptoms in the first or in the second case [17]. With the development of new technical forms of radiation therapy, differences in the frequency and severity of skeletal radiation damages were noted. For the first time, the general patterns of radiation damage to bones were demonstrated in a study of W. Howland et al., in 1975 [18]. Regardless of the type of ionizing radiation used in the study groups (beta radiation with an energy of 200 kilovolts, $25 \mathrm{MeV}$ and gamma radiation from a ${ }^{60} \mathrm{Co}$ source), all patients had a radiographic sequence of trabeculae thickening, thickening of the cortical layer, local and then diffuse demineralization, the appearing foci of sclerosis, cystic reor- 
ралізації, поява вогнищ склерозу, кістозна перебудова трабекулярної речовини, що, на думку авторів, відповідало атрофії кісткової тканини. Водночас, істотні відмінності відзначалися в групі пацієнтів, які отримували бета-терапію енергією 200 кіловольт. Серед них зареєстрована достовірно більша кількість переломів, остеонекрозів і остеомієліту порівняно з рештою. Автори також відзначили дозозалежний ефект у проявах вказаних ускладнень, акцентуючи на тому, що менша енергія іонізуючого випромінювання веде до більш виражених форм променевого ушкодження кісткової тканини.

3 позиції біомеханіки, кістки таза зазнають максимального вагового навантаження, що передається від тулуба через хребет і розподіляється через крижі, сакроілеальні суглоби та клубові кістки на нижні кінцівки через голівки і шийки стегнових кісток. Цією обставиною пояснюються результати ретроспективного дослідження J. Kwon, який аналізує структуру специфічних переломів кісток таза у пацієнток, яким проводилася променева терапія 3 приводу раку шийки матки [19]. Найчастіше переломам піддавалася латеральна маса крижів у зоні правого (62 \%) і лівого (58 \%) сакроілеального суглоба, тіло крижів (29 \%) і тіло клубової кістки (17\%). Прикметно, що переломи голівок стегнових кісток, як і переломи гілки лонної кістки, відзначалися в 1 \% спостережень. Разом з тим, дегенеративно-дистрофічні зміни кісток осьового скелета у цієї категорії пацієнток практично не відзначались.

Максимальна толерантна доза для кістки у дорослої людини складає 65-70 Гр. Використання джерел з мегавольтною енергією і можливості 3D-моделювання надають можливість не лише найточніше фокусувати поглинену дозу в цільовому вогнищі, але й максимально зменшити променеве навантаження на критичні органи [20]. Саме тому такі пізні ускладнення променевої терапії, як специфічні переломи кісток таза, з широким застосуванням 3D-конформної променевої терапії стали траплятися набагато рідше.

У приведеному нами спостереженні міститься опис якнайбажанішого ефекту від 3-конформної променевої терапії, а саме повного клініко-радіологічного регресу первинного місцево поширеного раку прямої кишки, зафіксований досить значний 2-річний безрецидивний період, так і досить рідкісного і нехарактерного віддаленого ефекту дії іонізуючого випромінювання на критичні органи, а саме - білатеральний аваскулярний некроз латеральної маси крижі. ganization of trabecular substance, which, according to the authors, corresponded to atrophy of bone tissue. At the same time, significant differences were observed in the group of patients receiving beta therapy with an energy of 200 kilovolts. Among them there was a significantly greater number of fractures, osteonecrosis and osteomyelitis compared with the rest. The authors also noted a dosedependent effect in the manifestations of these complications, emphasizing that the lower energy of ionizing radiation leads to more pronounced forms of radiation damage to the bone tissue.

From the standpoint of biomechanics, the pelvic bones undergo a maximum weight load, transmitted from the body through the spine and distributed through the sacrum, sacroilial joints and iliac bones to the lower limbs through the heads and neck of the femoral bones. This circumstance explains the results of a retrospective study by J. Kwon et al., analyzing the structure of specific fractures of the pelvis in patients undergoing radiation therapy for cervical cancer [19]. The lateral masses of the sacrum in the zone of the right (62\%) and left (58\%) sacroilial joint, the body of the sacrum $(29 \%)$ and the body of the ilium (17\%) were convicted to the most frequent fractures. It is noteworthy that fractures of the femoral heads, as well as fractures of the branch of the pubic bone, were observed in $1 \%$ of cases. At the same time, degenerative and dystrophic changes in the bones of the axial skeleton in this category of patients were practically not observed.

The maximal tolerant radiation dose for bone in an adult is $65-70$ Gy. The use of sources with megavolt energy and the possibility of 3D modeling makes it possible not only to focus the absorbed dose most accurately in the target focus, but also to minimize the radiation influence on critical organs [20]. That is why such late complications of radiotherapy as specific fractures of the pelvic bones, have become much less common with the extensive use of 3D conformal radiotherapy.

Our case report contains a description of the most desirable effect of 3D - conformal radiotherapy, namely the complete radiological regression of the primary locally advanced rectal cancer, which has an inspiring recurrence-free period of two years, and a rather rare and unfavorable longterm effect on critical organs, namely, bilateral avascular necrosis of the lateral masses of the sacrum. 


\section{ВИСНОВОК}

Незважаючи на стандартизовану і прецизійну техніку планування, фракціонування і дозиметричного контролю за проведенням неоад'ювантної хіміопроменевої терапії з приводу місцево поширеного раку прямої кишки, біологічні ефекти іонізуючого випромінювання на критичні органи можуть носити різноманітний характер як за часом виникнення, так і за своєю структурою. Оцінюючи ефект неоад’ювантної хіміопроменевої терапії, слід брати до уваги можливість розвитку навіть дуже рідкісних ефектів іонізуючого випромінювання з боку критичних органів і включати їх раннє виявлення в діагностичний алгоритм.

\section{ІНФОРМАЦІЙНА УГОДА}

Перед публікацією наведеного вище клінічного випадку пацієнт заповнив письмову інформовану угоду, що дає дозвіл на використання його персональних даних.

\section{СПИСОК ВИКОРИСТАНИХ ДЖЕРЕЛ}

1. Bone complications after pelvic radiation therapy: evaluation with MRI / G. Ugurluer, T. Akbas, T. Arpaci et al. J. Med. Imaging Radiat. Oncol. 2014. Vol. 58, no. 3. P. 334-340. DOI: https://doi.org/ 10.1111/1754-9485.12176.

2. Daldrup-Link H. E., Henning T., Link T. M. MR imaging of therapy-induced changes of bone marrow. Eur. Radiol. 2007. Vol. 17(3). P. 743-361. DOI: https://doi.org/10.1007/s00330-0060404-1.

3. Transanal endoscopic microsurgery in treatment of small rectal $\mathrm{T} 1$ highrisk, T2 and T3 carcinomas combined with radiochemotherapy / M. Amann, J. Burghardt, C. Stratz et al. Eur. Surg. 2015. Vol. 47(5). P. 226-237. DOI: 10.1186/1477-7819-10-255.

4. Preoperative radiotherapy and local excision of rectal cancer with immediate radical re-operation for poor responders: a prospective multicentre study / K. Bujko, P. Richter, F. M. Smith et al. Radiother. Oncol. 2013. Vol. 106(2). P. 198-205. DOI: https://doi.org/10.1016/ j.radonc.2012.12.005.

5. CARTS Study Group. Chemoradiation therapy for rectal cancer in the distal rectum followed by organ-sparing transanal endoscopic microsurgery (CARTS study) /M. Verseveld, E. J. de Graaf, C. Verhoef et al. Br. J. Surg. 2015. Vol. 102(7). P. 853-860. DOI: https://doi.org/ 10.1002/bjs.9809.

6. Watch and wait approach following extended neoadjuvant chemoradiation for distal rectal cancer: are we getting closer to anal cancer management? / A. Habr-Gama, J. Sabbaga, J. Gama-Rodrigues et al. Dis. Colon Rectum. 2013. Vol. 56(10). P. 1109-1117. DOI: 10.1097/DCR.0b013e3182a25c4e.

7. Effect of pelvic irradiation on gastrointestinal function / E. Yeoh, M. Horowitz, A. Russo et al. Am. J. Med. 1993. Vol. 95. P. 397-406. DOI: 10.1016/0002-9343(93)90309-d.

\section{CONCLUSION}

Despite the standardized and precise planning, fractioning and dosimetric monitoring techniques for neoadjuvant chemoradiation therapy for locally advanced rectal cancer, the biological effects of ionizing radiation on critical organs can be varied both in time of occurrence and in structure. Evaluating the effect of neoadjuvant chemoradiation therapy, one should take into account the possibility of the development of even very rare effects of ionizing radiation on critical organs and include their early detection in the diagnostic algorithm.

\section{INFORMED CONCERN}

Before the publication of the present clinical case, the patient filled out a written informed concern approving the use of his personal data in scientific purposes.

\section{REFERENCES}

1. Ugurluer G, Akbas T, Arpaci T, Ozcan N, Serin M. Bone complications after pelvic radiation therapy: evaluation with MRI. $J$ Med Imaging Radiat Oncol. 2014;58(3):334-40. DOI: https://doi.org/ 10.1111/1754-9485.12176.

2. Daldrup-Link HE, Henning T, Link TM. MR imaging of therapyinduced changes of bone marrow. Eur Radiol. 200;17(3):743-61. DOI: https://doi.org/10.1007/s00330-006-0404-1.

3. Amann M, Burghardt J, Stratz C, Buess GF, Modabber A. Transanal endoscopic microsurgery in treatment of small rectal T1 highrisk, T2 and T3 carcinomas combined with radiochemotherapy. Eur Surg. 2015;47(5):226-237. DOI: 10.1186/1477-7819-10-255.

4. Bujko K, Richter P, Smith FM, Polkowski W, Szczepkowski M, Rutkowski $A$, et al. Preoperative radiotherapy and local excision of rectal cancer with immediate radical re-operation for poor responders: a prospective multicentre study. Radiother Oncol. 2013;106(2):198-205. DOI: https://doi.org/10.1016/j.radonc. 2012.12.005.

5. Verseveld M, de Graaf EJ, Verhoef C, van Meerten E, Punt CJ, de Hingh IH, et al. CARTS Study Group. Chemoradiation therapy for rectal cancer in the distal rectum followed by organ-sparing transanal endoscopic microsurgery (CARTS study). $\mathrm{Br} J$ Surg. 2015;102(7):853-60. DOl: https://doi.org/10.1002/bjs.9809.

6. Habr-Gama A, Sabbaga J, Gama-Rodrigues J, Sao Juliao GP, Proscurshim I, Bailao Aguilar P, et al. Watch and wait approach following extended neoadjuvant chemoradiation for distal rectal cancer: are we getting closer to anal cancer management? Dis Colon Rectum. 2013;56(10):1109-17. DOI: 10.1097/DCR.0b013e3182a25c4e.

7. Yeoh E, Horowitz M, Russo A, Muecke T, Robb T, Maddox A, Chatterton B. Effect of pelvic irradiation on gastrointestinal function. Am J Med. 1993; 95: 397-406. DOI: 10.1016/0002-9343(93)90309-d. 


\section{КЛІНІЧНА}

8. How patients manage gastrointestinal symptoms after pelvic radiotherapy / B. Gami, K. Harrington, P. Blake et al. Aliment. Pharmacol. Ther. 2003. Vol. 18. P. 987-994. DOI: https://doi.org/10.1046/j.13652036.2003.01760.x.

9. Hauer-Jensen M., Wang J., Denham J. W. Bowel injury: current and evolving management strategies. Semin. Radiat. Oncol. 2003. Vol. 13(3). P. 357-371. DOI: https://doi.org/10.1016/S10534296(03)00032-8.

10. Andreyev J. Gastrointestinal symptoms after pelvic radiotherapy: a new understanding to improve management of symptomatic patients. Lancet Oncol. 2007. Vol. 8(11). P. 1007-1017. DOI: https://doi.org/ 10.1016/S1470-2045(07)70341-8.

11. Fuccio L., Guido A., Andreyev H. J. Management of intestinal complications in patients with pelvic radiation disease. Clin. Gastroenterol. Hepatol. 2012. Vol. 10(12). P. 1326-1334.e4. DOI: https://doi.org/ 10.1016/j.cgh.2012.07.017.

12. Morris K. A., Haboubi N. Y. Pelvic radiation therapy: between delight and disaster. World J. Gastrointest. Surg. 2015. Vol. 7(11). P. 279288. DOI: 10.4240/wjgs.v7.i11.279.

13. Andreyev J. Gastrointestinal complications of pelvic radiotherapy: are they of any importance? Gut. 2005. Vol. 54(8). P. 1051-1054. DOl: 10.1136/gut.2004.062596.

14. Hopewell J. W. Radiation-therapy effects on bone density. Med. Pediatr. Oncol. 2003. Vol. 41. P. 208-211. DOI: https://doi.org/ 10.1002/mpo.10338.

15. Eiving J. Radiation osteitis. Acta Radiol. 1926. Vol. 6. P. 399-412. DOI: https://doi.org/10.3109/00016922609139503.

16. Paul L. W., Pohle E. A. Radiation osteitis of the ribs. Radiology. 1942. Vol. 38. P. 543-549.

17. Guttenberg S. A. Osteoradionecrosis of the jaw. Am. J. Surg. 1974. Vol. 127. P. 326-332. DOI: https://doi.org/10.1016/00029610(74)90042-7.

18. Postirradiation atrophic changes of bone and related complications / W. J. Howland, R. K. Loeffler, D. E. Starchman, R. G. Johnson. Radiology. 1975. Vol. 117(3 Pt 1). P. 677-685. DOI: https://doi.org/ 10.1148/117.3.677.

19. Pelvic bone complications after radiation therapy of uterine cervical cancer: evaluation with MRI / J. W. Kwon, S. J. Huh, Y. C. Yoon et al. AJR Am. J. Roentgenol. 2008. Vol. 191(4). P. 987-994. DOI: 10.2214/AJR.07.3634.

20. Pelvic bone complications following radiation therapy of gynecologic malignancies: clinical evaluation of radiation-induced pelvic insufficiency fractures / H. Ikushima, K. Osaki, S. Furutani et al. Gynecol. Oncol. 2006. Vol. 103. P. 1100-1104. DOl: https://doi.org/10.1016/ j.ygyno.2006.06.038.

\section{ІНФОРМАЦІЯ ПРО АВТОРІВ}

Віталій Васильович Звірич - лікар-хірург-онколог, завідувач відділення онкоколопроктології, Національний інститут раку, Київ, Україна
8. Gami B, Harrington K, Blake P, Dearnaley D, Tait D, Davies J, et al. How patients manage gastrointestinal symptoms after pelvic radiotherapy. Aliment Pharmacol Ther. 2003; 18: 987-94. DOI: https://doi.org/10.1046/j.1365-2036.2003.01760.x.

9. Hauer-Jensen M, Wang J, Denham JW. Bowel injury: current and evolving management strategies. Semin Radiat Oncol. 2003;13(3):357-71. DOI: https://doi.org/10.1016/S10534296(03)00032-8.

10. Andreyev J. Gastrointestinal symptoms after pelvic radiotherapy: a new understanding to improve management of symptomatic patients. Lancet Oncol. 2007;8(11):1007-17. DOI: https://doi.org/10.1016/S1470-2045(07)70341-8.

11. Fuccio L, Guido A, Andreyev HJ. Management of intestinal complications in patients with pelvic radiation disease. Clin Gastroenterol Hepatol. 2012;10(12):1326-34.e4. DOI: https://doi.org/10.1016/j.cgh.2012.07.017.

12. Morris KA, Haboubi NY. Pelvic radiation therapy: between delight and disaster. World J Gastrointest Surg. 2015;7(11):279-88. DOI: 10.4240/wjgs.v7.i11.279.

13. Andreyev J. Gastrointestinal complications of pelvic radiotherapy: are they of any importance? Gut. 2005;54(8):1051-4. DOI: 10.1136/gut.2004.062596.

14. Hopewell JW. Radiation-therapy effects on bone density. Med Pediatr Oncol. 2003; 41:208-11. DOI: https://doi.org/ 10.1002/mpo.10338.

15. Eiving J. Radiation osteitis. Acta Radiol. 1926;6:399-412. DOI: https://doi.org/10.3109/00016922609139503.

16. Paul LW, Pohle EA. Radiation osteitis of the ribs. Radiology. 1942;38:543-49.

17. Guttenberg SA. Osteoradionecrosis of the jaw. Am J Surg. 1974;127:326-32. DOI: https://doi.org/10.1016/00029610(74)90042-7.

18. Howland WJ, Loeffler RK, Starchman DE, Johnson RG. Postirradiation atrophic changes of bone and related complications. Radiology. 1975;117(3 Pt 1):677-85. DOl: https://doi.org/ 10.1148/117.3.677.

19. Kwon JW, Huh SJ, Yoon YC, Choi SH, Jung JY, Oh D, Choe BK. Pelvic bone complications after radiation therapy of uterine cervical cancer: evaluation with MRI. AJR Am J Roentgenol. 2008;191(4):987-94. DOI: 10.2214/AJR.07.3634.

20. Ikushima H, Osaki K, Furutani S, Yamashita K, Kishida Y, Kudoh T, Nishitani H. Pelvic bone complications following radiation therapy of gynecologic malignancies: clinical evaluation of radiation-induced pelvic insufficiency fractures. Gynecol Oncol. 2006; 103:1100-4. DOI: https://doi.org/10.1016/j.ygyno. 2006.06.038.

\section{INFORMATION ABOUT AUTHORS}

Vitalii V. Zvirych - staff surgical oncologist, Head of Oncocoloproctology Department, National Cancer Institute, Kyiv, Ukraine 
Дмитро Ельдарович Махмудов - кандидат медичних наук, лікар-хірург-онколог, старший науковий співробітник, відділення онкоколопроктології, Національний інститут раку, Київ, Україна

Андрій Валерійович Ашихмін - лікар-радіолог, відділення променевої діагностики, Національний інститут раку, Київ, Україна

Олена Олександрівна Колеснік - доктор медичних наук, головний науковий співробітник науково-дослідного відділення органів черевної порожнини та заочеревинного простору, Директор Національного інституту раку, Київ, Україна
Dmytro E. Makhmudov - Candidate of Medical Sciences, surgical oncologist, Senior Research Associate, Oncocoloproctology Department, National Cancer Institute, Kyiv, Ukraine

Andriy V. Ashykhmin - staff radiologist, Department of Radiology, National Cancer Institute, Kyiv, Ukraine

Olena 0. Kolesnik - Doctor of Medical Sciences, Chief Scientific Officer of the Research Department of the Abdominal and Peritoneal Organs, Director of National Cancer Institute, Kyiv, Ukraine 